\title{
High school learners experiences of gangsterism in Hanover Park
}

\author{
Mufaro Magidi, Rinie Schenk and Charlene Erasmus
}

\begin{abstract}
The culture of gang violence has become deeply entrenched in South Africa. The present study explored the experiences of non-gang school-going adolescents regarding gangs and gangsterism in Hanover Park in the Western Cape. A qualitative exploratory approach was used. Data collection instruments were focus group discussions supported by qualitative semi-structured interviews involving 18 adolescents between the ages of 16 and 18 from two secondary schools in Hanover Park, Cape Town. The data were thematically analysed. The results have shown that the presence of gangs affects the learners' school attendance, restricts their mobility, increases bullying at school and seriously disrupts family and community life.
\end{abstract}

"Once found principally in large cities, violent street gangs now affect public safety, community image, and quality of life in communities of all sizes in urban, suburban, and rural areas. .... Gangs affect society at all levels, causing heightened fears for safety, violence, and economic costs". (National Gang Threat Assessment, 2005:139).

\section{CONTEXTUAL BACKGROUND TO THE STUDY}

An increase of gang-related crimes and illegal activities is being experienced by communities in South Africa. In the Daily Maverick of 26 May 2014 it was stated that gang related murders in South Africa increased by 86\% between 2012-2014. Gang membership is no longer limited to people of a minority but has evolved into accommodating people from all psychosocial structures such as race, socio-economic status, ethnicity, and culture (Egley and Howell, 2011). The culture of gang violence has become deeply entrenched in South Africa and is worse in the Western Cape Province in certain areas such as Manenberg and Hanover Park (South African History Online, 2011). This can be noted in an increase in televised and newsprint articles displaying children and community members shot, injured and in some cases killed by gang violence.

In communities where gangs are prevalent, one cannot overlook the experiences and the effects of gangs on non-gang-affiliated residents. Lindsay (2012), Marcovitz (2010), Kelly (2008) and Kemp (2007) acknowledged that gangs have an effect on societies which inevitably lead to responses in members of society such as fear, and vulnerability. 
Although scholars (Lindsay, 2012; Marcovitz, 2010; Kelly, 2008; Kemp, 2007) have identified the different effects and experiences communities and individuals have as a result of gangs, they have not in particular targeted the experiences of adolescents. Howell and Gleason (1999) consider that, despite the lack of research about the effects of gangs on adolescents, one may safely assume that adolescents are even more vulnerable than any other age group, as theirs is the age where they are recruited to become gang members. This is the stage in their lives where their need for identity and belonging (affiliation), have to be met (Klein, 1995). The adolescent stage, a stage of high turmoil, can be worsened by social risk factors that may add to the vulnerability of adolescents to recruitment into gang membership (Howell and Griffiths, 2016; Shaffer, 2009; Branch, 1997). Howell and Griffiths (2016) further explain that the greater and more complex risk factors, such as poverty, neglect, abuse, bullying that adolescents are exposed to, the more vulnerable they will become to being drawn into gang involvement. This study, therefore, aimed to explore and describe the experiences of non-gang adolescents regarding gangs and gangsterism in Hanover Park, Western Cape. This article also adds to the scarce literature on gangs and gangsterism in South Africa and in particular in social work.

\section{DEFINING GANGS}

One of the greatest impediments to the collection of accurate gang-related data is the lack of a national uniform or single generally accepted definition of a gang or gangsterism (National Gang Threat Survey, 2009). A common denominator across all definitions given of gangs is the use of the term 'group', which highlights the view that despite the overlapping activities, gangs generally operate on the principle of a group of more than three individuals (National Institute of Justice (NIJ), 2015). Common to all the different definitions and views given on the identification of gangs, is the view that gangs adopt a group identity, thrive on high crime, and are able to ground themselves or become established in a community's core such as schools, churches, and political and economic venues (NIJ, 2015; Moore, 1991).

Egley, Howell and Major's (2006) definition best describe gangs as organisations of three or more individuals who form an alliance for a common purpose which identifies with and claims territory in the community and engages individually or collectively in violence and other criminal activities. Key to the adopted definition is that gangs are territorial and thrive on intimidation, fear and criminal activities.

In South Africa the traditional view of gangs includes the so called 'skollies' who operate mainly on the Cape Flats as noted by Van Wyk (2001) and Broidy and Agnew (1997). Currently street and prison gangs have become organised and rooted in communities. Prison gangs who operate within prisons have started to recruit outside members, especially those who belonged to street gangs (Van Wyk and Theron, 2005; Van Wyk, 2001; Fong and Buentello, 1991). Similar trends are also witnessed and experienced in Hanover Park, where alleged street gang members have been observed acting on behalf of prison gang members. 
A documented gang in the Western Cape that operated in areas such as Manenberg and Hanover Park is the Hard Livings, which is one of the largest gangs in the Western Cape (Bernburg, Krohn and Rivera, 2006). Until 1994, the Hard Livings was one of the biggest gangs on the Cape Flats with an estimated membership of between 3000 and 10000 members. This number is estimated to have grown to over 30 ooo members in 2005 (Bernburg et al., 2006). Updated numbers could not be found. Kissner and Pyrooz (2009) noted the strength and evolution of the gang by stating that it now has stakes in foreign syndicates with better resources to bring drugs into the country. Street gangs such as the Hard Livings and Laughing Boys are, therefore, no longer characterised by youngsters who hang around the streets of local communities to 'defend' the community from rival gangsters, but instead have developed into organised criminal empires (National Gang Threat Assessment Centre, 2005), so much so, that reference is made to the 'Cape of fear', leaving communities and in particular adolescents, vulnerable and powerless (Van Wyk, 2001; Kinnes, 2000).

\section{METHODOLOGY}

A qualitative, exploratory and contextual research design was used which is a form of social enquiry that focuses on the way people interpret and make sense of their experiences and the world in which they live (Holloway and Wheeler, 2002). Polit and Beck (2004), and Munhall (2001) point out that the richness and depth of the description gained from a qualitative approach provides a unique appreciation of the reality of the experience, as it emphasises the dynamic, holistic and individual aspects of the human experience and attempts to capture those experiences in their entirety in their natural context.

The study sample was derived from a population of high school learners in Hanover Park. Purposive sampling was used to select registered adolescent learners for the focus group dis-cussions from the two high schools, Crystal High School and Mountview High School. In order to be included in the study, participants had to be school-going adolescents registered at either of the high schools, residents of Hanover Park, preferably doing Grade 11, aged be-tween 16 and 18, not be a gang member, and be willing to participate. A total of 36 participants (18 learners from each school) were selected. Through snowball sampling, a grade 10 learner was selected on the grounds of having relevant personal experiences to share.

Focus group discussions, with a semi-structured interview guide in a permissive nonthreatening environment (Bloor, Frankland, Thomas and Robson, 2001), were used to aid and facilitate the process of data collection. Learners who requested to share information outside the focus group context were accommodated through a semi-structured individual interview. Semi-structured interviews are verbal interchanges where the interviewer attempts to elicit particular information from another person by asking open ended questions (Robson, 2011; Krueger and Casey, 2000). The semi-structured interview guidelines allowed the in-depth exploration of experiences, views and perceptions of the participants. Focus group discussions and interviews were aided by observations. 
The data were analysed using thematic analysis. Thematic data analysis, described by Creswell (2003) and Miles and Huberman (1994), involves the creation and application of codes and themes to data. Trustworthiness of the results was ensured through open, honest and unbiased exploration, analysis and reporting of data and triangulation with literature (Robson, 2011). Ethics considerations of informed consent, confidentiality and no harm done were applied and special care was taken to ensure the safety of the learners. Ethical clearance was obtained from the Research and Ethics Committee from the University of the Western Cape.

\section{RESULTS AND DISCUSSION \\ Some context observations}

The following observations are an indication of the gang presence in Hanover Park. Graffiti of gang signs and gang names such as Young Americans, Mongrels, Sexy Boys, Hard Livings, and Laughing Boys on school walls, community halls, bus stops, private property and roads are very visible in communities as illustrated in photo 1 on the following page. The graffiti show the visibility and act as territory markers by the different gangs.

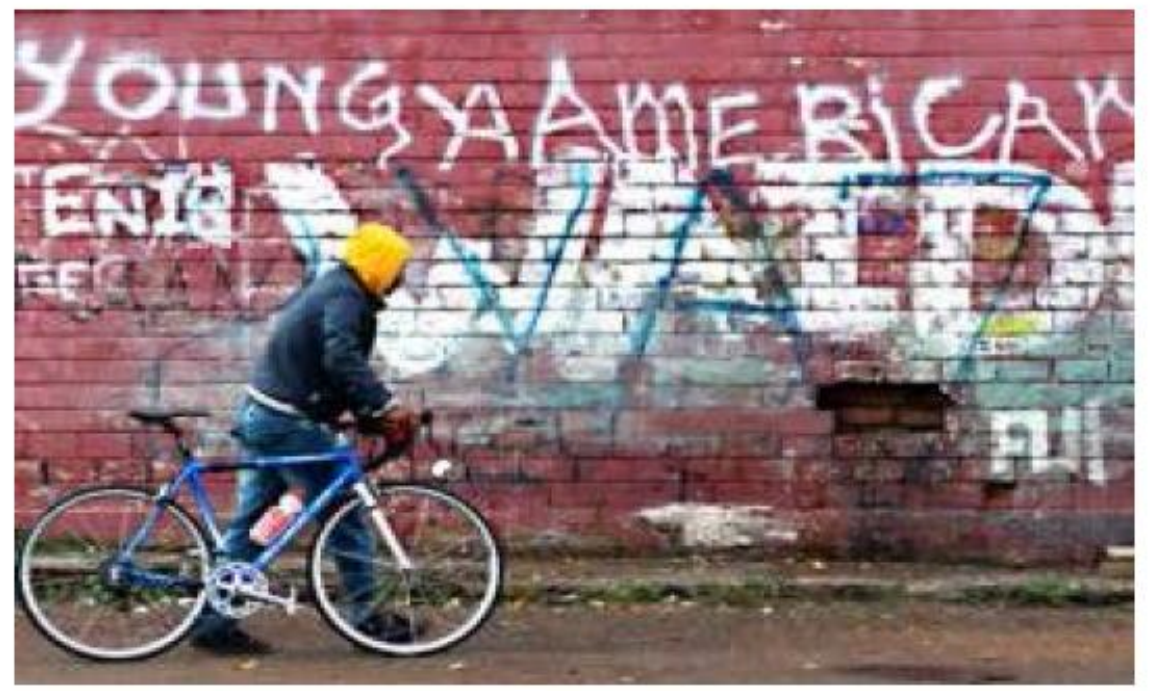

Photo 1: Graffiti indicating the gang Young Americans' territory in Como Court, Hanover Park (Source: Underhill, 2013)

Gang shootings are noticeably a common and regular occurrence in the community of Hanover Park. Incidents of gang shootings may occur any time during the day and will transform the community in a matter of seconds. Within minutes into the shootings, the streets are cleared and after the shooting, the community carries on with its daily activities. 


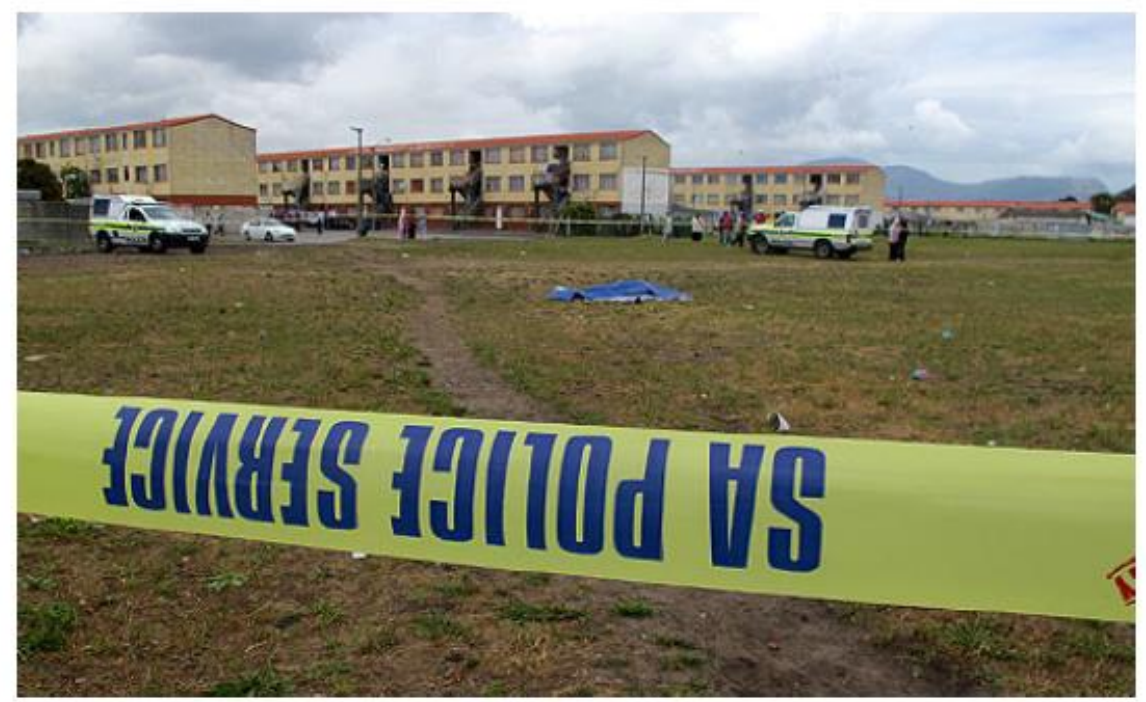

Photo 2: Man shot dead in Hanover Park (Source: Fisher, 2013)

Some actions relating to the curbing of gang violence were observed: Both primary and high schools in Hanover Park have adopted strict controlled access to prevent the entrance of gangs to school premises, painting of graffiti and harassing of educators. Police raids took place regularly in the area, pulling aside members of the public for random drug and weapon searches. Police officers raid houses of suspected drug merchants as well as schools when they suspect that learners may be selling drugs or carrying weapons (see Photo 3 below):

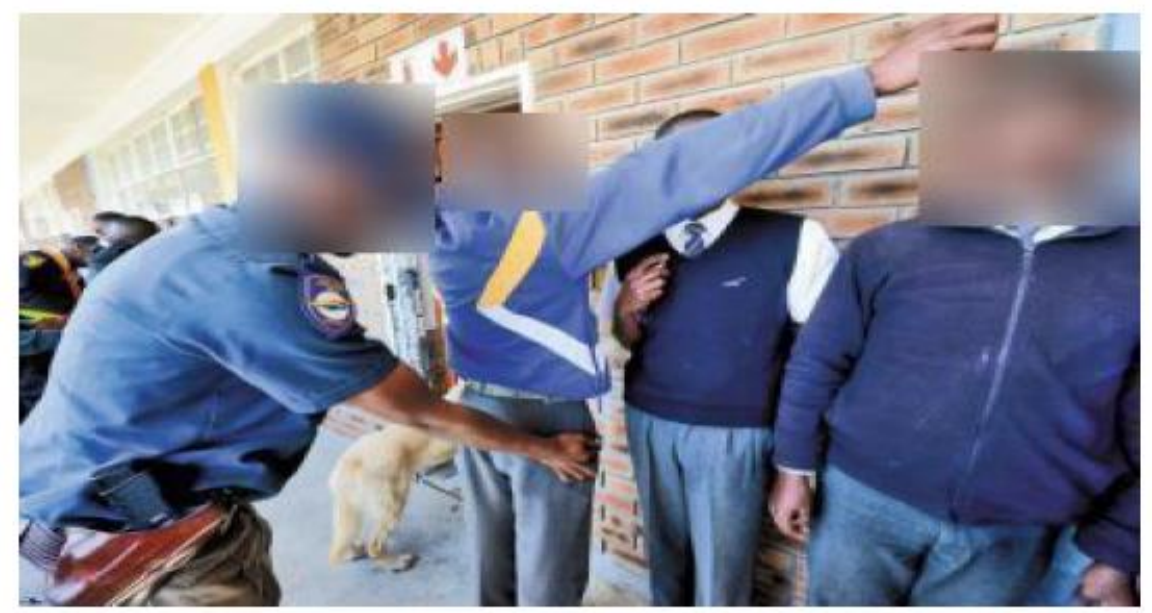

Photo 3: Police raid school (Source: Kotlolo, 2013)

Driving through the community, one will also notice gang members positioned in groups on street corners (see photo 4 on the following page). The gangs are usually just sitting and seem to be having discussions and loitering around, intimidating community members. Street corners are hubs for selling drugs and used by the gangs to demarcate gang zones. 


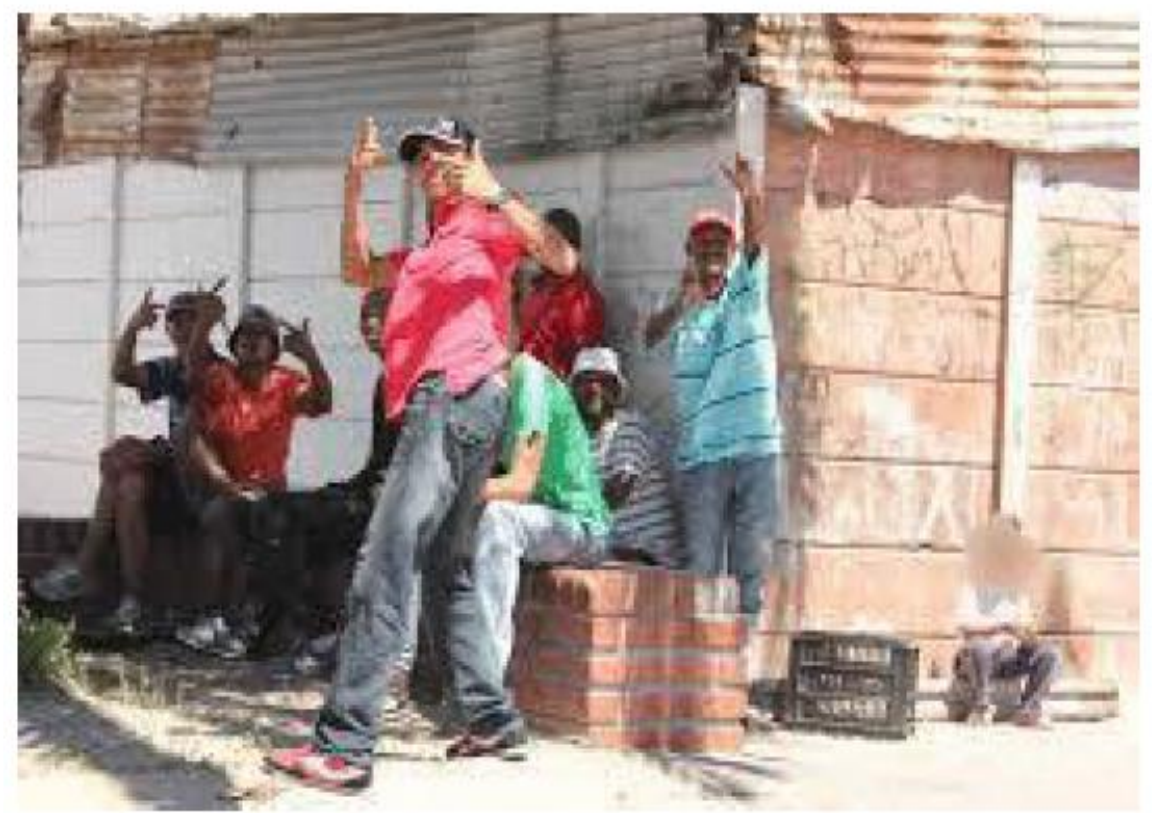

Photo 4: Gangs gathering at a street corner in Hanover Park (Source: Kretzmann, 2012)

More disturbing was the fact that gang members wait at school gates, when schools close for the day and engage with learners. Hess (2013) reports that gangs have largely replaced government authorities and filled the vacuum left by the lack of jobs, social services, parenting and recreational facilities. They organise everything from cash for school uniforms, a free taxi ride to hospital, to provide rent money and support soccer tournaments (Hess, 2013). One can assume that this type of support offered by gangs may attract some members of the community as a positive and desirable entity with whom to interact. They are, therefore, an integral part of the functioning of the community.

Gangs are furthermore easily recognisable by their tattoos, such as the number 27 and 26 on ex-prison gangsters, while the Laughing Boys gangs are easily recognisable by comic and cartoon character tattoos on their faces and arms. Gangs in Hanover Park, when inducting new members into their gangs, officialise the process by what community members refer to as 'sticking a chappy' (the phrase 'chappy' is used to refer to gang tattoos which identify the individual as part of the gang). These tattoos are usually put on visible body parts like arms, neck and face, where they can be clearly displayed to the public or opposite gang members as an act of intimidation as illustrated in photos 5 and 6 on the following page: 


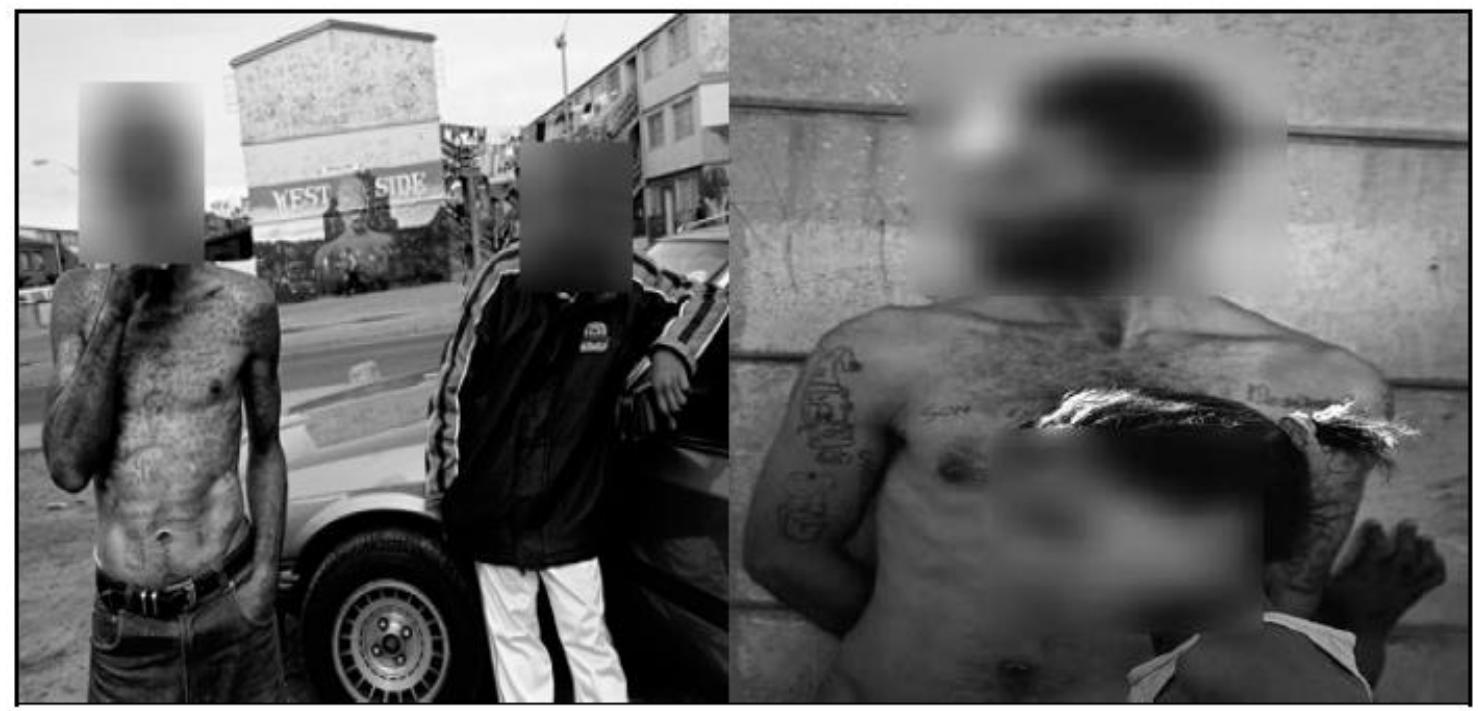

Photo 5 and Photo 6: Laughing-Boys gang member's' pride in their gang tattoos (Source: Pinnock, 2013)

\section{Results from the focus groups and interviews}

Participants' profiles

Between the two schools, 36 participants participated in the study, with each school providing an equal number of male and female learners. Thirty of the participants were 16 years old, while 6 of them were 15 years old. One learner was in grade 10 and the rest were all grade 11 learners.

\section{Discussion of themes}

- Gangs take control over the communities:

MnCube and Steinman (2014) and Covington and Taylor (1991), state that control of communities is taken by gangs through creating fear and intimidation. Fear is a daily everpresent factor among community members who reside in gang-infested communities and schools. They develop 'self-recognition' with a special vocabulary, clothing, signs, tattoos, colours and territorial graffiti (Klein, 1995). They are visible, organised and well equipped with weapons and budgets (Mncube and Steinman, 2014; Klein, 1995). Lane and Meeker (2000) also confirm that gang members that rule by intimidation, often extorting money from learners and forcing them to hand over lunch, money, new coveted pieces of clothing, or even homework and assignments.

In the interviews with the learners some of the participants reported that they live in fear, and that they are concerned about being robbed, stabbed or worse, being shot dead by the gangs: 
"I had to literally run for my life one day when I decided to take a short cut going to Shoprite. Like gangs in my street they don't walk in Grove Road but it's shorted and when the Dixies in Grove Road saw me...they started chanting, it was in Afrikaans ... and after that I ran. They just wanted to scare me off, I think."

On the other hand another participant shared that they do not really fear the gangs but learned how to live with their presence: "you cannot walk around Hanover Park dodging every corner or looking like you are scared and afraid because the gangs will notice that. Besides we are not scared like scared of the gangs, we grew up with these people and some of them we used to play with as kids so it's not like we fear them, we just know that they are there and they are bad people". Sanders (2012) refers to this as the 'normalisation' process when living in these circumstances. Although the participant does not 'fear' the gangs, he/she is very aware of their existence and the dangers linked to them such as the possibility of being shot and killed "... you can get shot and be killed anytime just because you belong to a different gang."

It was also further mentioned that the gangs also control the community with some positive effects. Where the police and other structures do not fulfil their roles, the gangs will step in:

"The gangs get a bad rap like everything is always blamed on them but I know sometimes and a lot of the times we get robbed by tik-kops (people using tik/crystal meth) that just want money to buy drugs and sometimes if you get robbed by a tik-kop you can actually report them to the gangs that stay in your section and they will go get it for you".

Van Wyk and Theron (2005) and Klein (1995) confirm the view that gangs take control of an area and the youth when the community and its institutions have failed in their tasks. The inability to control, care, and protect community members by formal institutions, provides the gap for gangs to take control. The effects of gangs in control of areas results in the themes that follow.

- Gang presence disrupts school functioning and learning:

It has emerged from the interviews that gangs are no longer restricted to street corners, prisons or poor societies, but are also openly present and operating within and affecting the community and school settings (Mncube and Steinman, 2014). According to a study conducted by US Department of Health and Human Services (2013), teens attending schools with gangs and drugs compared to teens attending schools without drugs and gangs, were twelve times more likely to miss out at least three days every week of schooling and three times more likely to have used alcohol. Finlay (2006) confirms that parents do not allow their children to go to school if they may be exposed to violence by gangs.

The participants reported staying out of school because of gang activity, which relates mostly to gang shooting: 
"If the gangs are shooting my mom does not allow me and my little sister to come to school because we have to walk to school from the back of Groenall Walk (street in Hanover Park) to here and you don't know what can happen when the gangs are fighting, staying at home is better rather than letting us go to school and then we don't come back home or we come back dead."

This was further confirmed by a participant that learners stay at home when gang fights are prevalent:

"Not every day, it's usually when a big gang is fighting another big gang. Like the Mongrels versus the Americans...and the ghettos that side of Hanover Park (gestures East). They can't come through this side because this side is Americans now all that children that attend Crystal must stay at home because they will shoot them also...sometimes you can't even walk to school. When you come to school they shoot right in the morning".

Participants shared that the longest time they had stayed out of school consecutively within the same week, was two days during gang shootings.

Another view point that emanated from the study related to the challenges of attending school, was that when the learners do make it to school, classes are regularly disrupted by gang-related incidents. The causes of disruption ranged from gang-affiliated learners fighting among themselves, to shootings happening in close proximity to schools and learners being asked to assume safety positions.

"Whenever we hear gun shots while in class, we all have to sit with our heads between our legs like an aeroplane that is going to crash because you never know where the bullet is coming from and our school walls are really small".

Another participant elaborated:

"We were sitting in class like normal and we heard a glass break but it wasn't in our class you see. Then we had the sound again and the teacher yelled that we must all lie but it wasn't even a gun, it wasn't just a car or something...but you see that's how jumpy we always are even in the middle of class".

Gangs negatively affect school attendance and functioning, and the context in which learners should learn is not conducive. Klein (1995) confirms that the proliferation of gangs has upset many school systems and that schools in the United States had to learn how to manage gangs, protect the learners and even get into the enforcement business - which seems not yet the case in South Africa (MnCube and Steinman, 2014)

- Increased bullying at school as a result of gangs: 
Gang presence increases the culture of violence and bullying and increases incidents of victimisation and bullying of both learners and teachers by gang members and non-gang members are prevalent (MnCube and Steinman, 2014). The learners at Mountview High School reported that: "It's not like we have a lot of gangsters here ..., it's just usual bullying like people picking on the nerd in class or the fat girl...or someone saying your Jou-ma se P\$\#@... \{sic\}(derogatory way of referring to his mother's genitals) you know".

Learners from Crystal High school however, indicated that the bullying was mainly being perpetuated by gangs within the school environment:

"You could be sitting in the playground and they just come and you know you have to move and give them a sit...or one day you know what happened to me on my way to school, this other laitie (boy) (sic) a gang member came to me and told me to pick dog shit and put it in my bag because he doesn't like litter...that's kak (swear word) my broe (brother)".

Taussig (2004) maintains that gang presence to a greater extent escalates levels of violence associated with bullying especially among teens, which includes being forced to do things such as carrying drugs, verbal threats and use of derogatory terms. It was also shared by the participants that some youth will even drop out of school or join the gangs to stop the process of bullying. Learners are left with no option but to join the gangs or be bullied with threats and physical assaults should they refuse to associate with the gang: "Some people that are weak will join so that they are not bullied anymore cause no one will ever-ever bully a gang my broe (brother) unless you wanna die...even teachers don't talk to gangs like they talk to us". This statement supports the view that in some cases, students do not actively seek out gang affiliation but can be bullied and drawn into the lifestyle. The statement made by the learner also confirms the power and control the gangs exhibits in the communities and over learners. An article by the Integrated Regional Information Networks (2007) suggests that gangsters recruit learners to do their dirty work which include carrying drugs, hiding weapons and fighting. These learners in return receive protection from bullying and any physical harm. The report further confirms that the recruitment is not always voluntary, and the refusal to join gangs when recruited, will lead to gangs exerting pressure on learners through violence and excessive bullying.

- Violence in schools as a result of gang activity:

According to a report published by the New York Department of Education (2011), 4.5\% to $7.5 \%$ of students in the USA carry some sort of weapon with them to school. Gonzales, Richards and Seeley (2002) further allege that some schools worldwide have become vaults for gang weapons as some learners see schools as safer environments to hide their weapons. The most common weapons used among students are scissors, knives and batons (Fingerhut, Ingram and Feldman, 1998). MnCube and Steinman (2014) also confirm the use of a variety of weaponry by gangsters in schools, such as guns, knives, bottles and sharpened pencils which are used to threat and control other learners. 
"It happened, there is this guy that we all know in class is a "Laughing Boy" (name of gang), he comes here with a pocket knife and he goes around threatening people ...he stabbed (a boy from another gang) him at school and that happens in the school toilet and he even threatened a teacher with a knife".

Learners further reported that many of the gang members in their class come to school with concealed knives or screwdrivers which are used when fighting:

"They carry the weapons but it's not like they go around stabbing us at school, they use them when they fight outside with other gang member because people from another gang can just approach them any time...don't get me wrong though, it is very scary sitting in class with someone you definitely know is carrying a knife or even worse, a gun". Another learner also stated having witnessed a friend with a gun at school: "I don't know where he got the gun but he just showed it to me under the desk in class, we did played (sic) with it but it didn't have bullets or anything".

Learners reported that they turn away from any threat rather than carrying any weapons to challenge or confront the gang members:

"I would never carry anything to school other than my books and pencil case, my mother would kill me and besides what if the police stops you and they find a knife, they will just think you are one of them (gangs)". Another learner confirmed: "You cannot go to war with gangs, they work as teams and there you will be alone and you don't want to upset them because they will send big people to hit. No one goes to war with gangs, if they fight, you walk away".

Horowitz and Schwartz (2011) maintain that the availability of weapons in schools has a psychological effect on the non-gang learners that they end up being conditioned to believe that violence is the way to resolve certain problems. These authors furthermore are of the opinion that gang behaviour, such as responding to insults and offences through violence, insults and carrying of weapons, leads to the normalisation and justification to carry weapons by everyone including non-gang-affiliated learners (Horowitz and Schwartz, 2011). This is, however, counter to statements made by all of the learners that participated in the study as they all reported that they would rather turn away from any threat rather than carrying any weapons to challenge or confront the gang members.

- Experiences of family disintegration due to involvement in gangs:

The control of gangs over communities spills over to affecting and controlling families. When gangs replace family systems it leads to family disintegration which affects the entire family and inevitably the learners. Skiba and Peterson (2000); Mayer and Leone (1999) all reported that gangs' lifestyles create a mindset of loyalty, pride and love for vulnerable youth who are disengaged from their families. Skiba and Peterson (2000) further report that when the young person comes from a dysfunctional family, where they may experience 
neglect or do not receive adequate attention from their parents and families, the gang can easily replace the family as a key influential factor;

"When your brother belongs to a gang and he is ordered to come rob you guys so that he can be captain, he will do it because that is how they go up the ranks and become captains and leader or just so that you can be respected by the gang, they don't care about their own families".

Klein (1995) also confirms gang members' need for status, identity and belonging at the expense of their own families:

"There is this girl here at school, her brother, he is also a gangster. They shot him through his face and his bullet came through the back of his head. His mommy came and shouted at the gangs but they continued to shoot and all this happened in front of his mother and they could have shot her as well".

Loyalty is tested by gangs, and in the process, families inevitably lose their family members. It is easy for a gang to replace family systems as gang members find a new family system that may be supportive or provide attention which may have been missing in their traditional family setting (Larson, Smith and Furlong, 2002).

Three of the participants openly revealed that they had brothers who were gang-affiliated. One participant stated that because of the gang violence, her mother did not allow her brother to come back home for fear that he might put the family at risk of being attacked by another gang:

"Like me, my brother we all know is a Laughing Boy and is doing drugs big time. We last saw him during Eid (Muslim religious day) last year and my mother does not want him home because she knows that another gang can come looking from him and find him with us...besides he steals anything he can get like spoons, TV aerial, DVDs also cause he is using tik (crystal meths) but I also miss him sometimes, it's not like he is a bad person, he would fight anyone who does something to me and I miss him sometimes but if I even mention his name to my mother then she gets angry".

In addition, it is not only families that are disintegrating as a result of a family member being part of a gang, but it also results in broader broken family ties: "People outside of Hanover Park they don't wanna come here, like I have aunts in Muizenberg that will never set foot in this place because they are scared gangs will rob them because of what they hear in the news. We have to go there if we want to see them". Families with gang member are not only experiencing disintegration but are put at risk in many ways (Decker and Van Winkle, 1996). Families of rival gangs become victims of violence as gangs may use them as pawns for sending strong messages to rival gangs. The powerlessness and vulnerability of the families is evident when family members are involved in gangs and, in doing so, are also controlled by the gangs. 
- Restricted mobility as a result of the gangs in the community:

Part of youth socialisation is to be mobile and social. Gangs in high risk communities control a territory which is not only restricting gang members, but extends to non-gang members as well:

"I cannot just visit my friends who stay where the Hard Livings are, and mina, I stay where the Laughing Boys area cause they just assume that any adult boy has been recruited by gangs...if I visit there now and you see how tall I am as a guy, they will been just think that I am a gangster myself so I can't go there".

It was significant that male participants' shared more concern about being mistaken for gang members, which restricts their mobility more than that of female learners. Female learners explained another form of restricted mobility:

"During the day I can go anywhere as long as its day time but at night if you go to the taxi rank or walk past Voorspoed primary (school), then you are asking to be raped".

Female learners' restricted mobility is time-specific which to a greater extent shows that another effect of gangs is the perpetuation of gender-specific fear on learners.

In short the learners experience that the gangs "Literally control our lives". Mobility, according to Wilcox and Land (1996), is an essential element of development for the youth to fully develop mentally and socially.

\section{CONCLUSION}

The theme of control and intimidation, which is the main characteristic of what defines a gang (Egley et al., 2006), was highlighted and integrated in other themes to the extent that gangs control the lives of those that are gang and non-gang related. Gang presence inhibits their socialisation, relationships, schooling, family life, and in principle their total growth, development and well-being as young people. In Theme 1, the resilience of the learners also emerged as they manage their way through this intimidating, violent school and society context. Already in 1995, Klein came to the conclusion that research on gangs is useful in understanding the impact they have on those around them. Burton and Leoschut (2012) confirm that the primary drivers of violence in school are rooted in the violent environment in which children live outside the school. This research also shows the lack of recent literature on gangs and gansterism in South Africa and even more in social work.

Van Wyk and Theron (2005) clearly state that the reasons for the presence and existence of gangs is the result of complex social and economic issues. Preventing gangs and gangsterism, according to the (Burton and Leoschut, 2012), needs a fundamental, coherent series of research by multi professional and institutions, and interventions that target parents, families, youths and communities. 
It is evident that processes and programmes focussing on reclaiming communities with and for their residents should be facilitated (Van Wyk and Theron, 2005). Collective efforts to address issues such as improved family life and well-being, parenting, youth development and employment and proper education is needed. Communities need to take responsibility and control with the support from policies, Government departments, civil society, institutions and the broader society. Social work, in particular, needs to play a much more active and prominent role in facilitating these efforts. It is of concern that social work is absent in the research and active prevention of gangs and gansterism and should be addressed at social work practice and research forums. 


\section{REFERENCES}

Bernburg, J.G., Krohn, M.D. and Rivera, C.J. (2006). "Official Labelling, Criminal Embeddedness and Subsequent Delinquency: A Longitudinal Test of Labelling Theory" Journal of Research in Crime and Delinquency 43:67-88.

Bloor, M., Frankland, J., Thomas, M. and Robson, K. (2001). Focus Groups in Social Research London: Sage.

Branch, C.W. (1997). Clinical Interventions with Gang Adolescents and their Families Colorado: Westview Press.

Broidy, L. and Agnew, R. (1997). "Gender and Crime: A General Strain Theory Perspective” Journal of Research in Crime and Delinquency 34:275.

Burton, P. and Leoschut L. (2012). Results of the 2012 National School Violence Study Cape Town: Centre for Justice and Crime Prevention (CJCP).

Covington, J. and Taylor, R. (1991). "Fear of Crime in Urban Residential Neighbourhoods: Implications of Between- and Within-neighbourhood Sources for Current Models" Sociological Quarterly 32:231-249.

Creswell, J.W. (2003). Research Design: Qualitative, Quantitative and Mixed Methods Approaches USA: Sage Publications.

Decker, S.H. and Van Winkle, B. (1996). Life in the Gang: Family, Friends and Violence Cambridge: Cambridge University Press.

Egley, A.J. and Howell, J.C. (2011). "The Impact of Gangs on Communities", http://www.nationalgangcenter.gov/content/documents/impact-of-gangs-oncommunities pdf (Accessed on 03/07/2012).

Egley, A.J., Howell, J.C. and Major, A.K. (2006). Recent Patterns of Gang Problems in the US: Results from the 1996-2002 National Youth Gang Survey in American Youth Gangs at the Millenium Long Grove: Waveland Press.

Fingerhut, L.A., Ingram, D.D. and Feldman, J.J. (1998). "Homocide Rates among US Teenagers and Young Adults: Differences by Mechanism, Level of Urbanisation, Race and Sex, 1987 through to 1995" Journal of the American Medical Association (JAMA) 280(5):423-427.

Finlay, K.A. (2006); Reengaging Youth in School: Evaluation of Truancy Reduction Demonstration Project Denver, Colorado: Foundation for Families and Children. 
Fisher, S. (2013). "Man Shot Dead in Hanover Park: Eye-Witness News", http://ewn.co.za/2013/09/04/Man-shot-dead-in-Hanover-Park(Accessed on 15/o8/2013).

Fong, R.S. and Buentello, S. (1991). "The Detection of Prison Gang Development: An Empirical Assessment” Federal Probation 55:66-69.

Gonzales, R., Richards, R. and Seeley, K. (2002). Youth Out of School: Linking Absence to Delinquency Denver: Colorado Foundation for Families and Children.

Hess, J. (2013). "Historic Gangs and Leaders", http://blogs.24.com/jeanihess/2013/05/25/ historic-gangs-and-leaders/(Accessed on 25/06/2013).

Holloway, I. and Wheeler, S. (2002). Qualitative Research in Nursing Oxford: Blackwell, Second Edition.

Horowitz, R. and Schwartz, G. (2011). Honour and Gang-delinquency London: Sage.

Howell, J.C. and Gleason, D.K. (1999). "Youth Gang Drug Trafficking" Juvenile Justice Bulletin, http://www.psychiatrictimes .com/showArticle.htm (Accessed on 19/07/2012).

Howell, J.C. and Griffiths, E.A. (2016). Gangs in America's Communities Thousand Oaks: Sage.

Integrated Regional Information Networks. (2007). "In Depth: Youth in Crisis and Coming of Age in the 21st Century", http://www.irinnews.org/pdf/in-depth/youth-incrisis-irin-indepth.pdf(Accessed on 25/04/2013).

Kelly, S.E. (2008). The Effects of Gangs and Gang Violence on Adolescents Dublin: ProQuest.

Kemp, R. (2007). "Ross Kemp Documentary on Gangs in Cape Town South Africa", http://www.liveleak.com/view?i=8c1 1188753669 (Accessed on 14/05/2012).

Kinnes, I. (2000). From Urban Streetgangs to Crime Empires: The Changing Face of Gangs in the Western Cape ISS Monograph No 48, Pretoria: Institute of Security Studies.

Kissner, J. and Pyrooz, D. (2009). "Self-control, Differential Association and Gang Membership: A Theoretical and Empirical Extension of the Literature" Journal of Criminal Justice 37:478-478.

Klein, M.W. (1995). The American Street Gang: Its Nature, Prevalence and Control New York: Oxford University Press. 
Kotlolo, M. (2013). "Police Seize Dagga during Raids on Two Schools", http://www.sowetanlive.co.za/news/2013/10/03/police-seize-dagga-during-raids-on-twoschools (Accessed on 17/10/2013).

Kretzmann, S. (2012). "Cape Town the Gang and Drug Capital of SA - MEC,": http://westcapenews.com/?p=4428 (Accessed on 15/o6/2013).

Krueger, R.A. and Casey, M.A. (2000). Focus Groups: A Practical Guide for Applied Research Thousand Oaks, CA: Sage Publications, Third Edition.

Lane, J. and Meeker, J.W. (2000). "Subcultural Diversity and Fear of Crime and Gangs" Crime and Delinquency 46:497-521.

Larson, J., Smith, D.C. and Furlong, M.J. (2002). "Best Practices in School Violence Prevention" in Thomas, A. and Grimes, J. (Eds.). Best Practices in School Psychology IV Bethesda, MD: National Association of School Psychologists, 1081-1097.

Lindsay, J. (2012). Gangs: Deal with it Before Wrong Seems Right Toronto: James Lorimer Limited.

Marcovitz, H. (2010). “Gangs: Juvenile Nonfiction” Science Research 35:181-209.

Mayer, M.J. and Leone, P.E. (1999). "A Structural Analysis of School Violence and Disruption: Implications for Creating Safer Schools" Re-education and Treatment of Children 22(3):333-356.

Miles, M.B. and Huberman, A.M. (1994). Qualitative Data Analysis: An Expanded Sourcebook Minnesota: Sage Publications.

Mncube, V. and Steinman, C. (2014). "Gang Related Violence in South African Schools" Journal for Social Sciences 39(2):203-211.

Moore, J.W. (1991). Going Down to the Barrio: Homeboys and Homegirls in Change Philadelphia: Temple University Press.

Munhall, P.L. (2001). Nursing Research: A Qualitative Perspective Los Angeles: Jones and Bartlett Learning.

National Gang Threat Assessment Centre. (2005). "National Alliance of Gang Investigators Associations", http://vault.fbi.gov/national-gang-threatassessment/2005/2005-part-01-of-01 Lview (Accessed on 14/02/2013).

National Gang Threat Assessment Centre. (2009). "Evaluation and Evolution of the Gang Resistance Education and Training (G.R.E.A.T.) Program USA", http://www.national gangcenter.gov/Publications/GREAT-Evaluation (Accessed on 12/10/2014). 
National Institute of Justice (NIJ). (2015). "What is a Gang?", http://www.nij.gov/ topics/crime/gangs/pages/definitions.aspx (Accessed on 31/10/2015).

New York Department of Education. (2011). "Weapons Report-suspensions and Expulsions" Student Discipline in Government Schools (PD 2006/0316).

Pinnock, D. (2013). "Best of 2013: Shooting Crime", http://www.mahala.co.za/reality/ shooting-crime/(Accessed on 15/10/2013).

Polit, D.F. and Beck, C.T. (2004). Nursing Research: Appraising Evidence for Nursing Practice Philadelphia: Wolters Klower/Lippincott Williams and Wilkins, Seventh Edition.

Robson, C. (2011). Real World Research London: Wiley, Third Edition.

Sanders, B. (2012). "Gang Youth, Substance Use, Patterns and Drugs Normalisation" Journal of Youth Studies 15(8):978-994.

Shaffer, D.R. (2009). Social and Personality Development Belmont: Wadsworth, Sixth Edition.

Skiba, R.J. and Peterson, R.L. (2000). "School Discipline at a Crossroads: From Zero Tolerance to Early Response” Exceptional Children 66(3):335-346.

South African History Online. (2011). "Gangs of Armed Men Kill at Least Twenty- six Commuters on a Train Travelling between George Goch and Denver Stations in Johannesburg”, http://www.sahistory.org.za/dated-event/gangs-armed-men-kill-leasttwenty-six-commuters-train-travelling-between-george-goch-(Accessed on 17/11/2012).

Taussig, D. (2004). "Gang Mentality" Philadelphia City Paper, December 16, http//:www.citypaper.net/articles/2004-12-16/cover.shtml(Accessed on 20/11/2013).

Underhill, G. (2013). "Gangs in Cape Town: A Daily Dance with Death", http://mg.co.za/article/2013-08-22-gangs-in-cape-town-a-daily-dance-with-death (Accessed on 17/11/2013).

US Department of Health and Human Services. (2013). "Bullying, Violence and Gangs", http://www.stopbullying.gov/blog/2013/05/14/bullying-violence-andgangs (Accessed on 17/10/2012).

Van Wyk, B.E. (2001). Constructions of Gang Membership among High School Youth (Unpublished Master's Dissertation) Stellenbosch: University of Stellenbosch, Department of Psychology. 
Van Wyk, B.E. and Theron, W. (2005). "Fighting Gansterism in South Africa: A Contextual Review of Gang and Anti-gang Movement in the Western Cape" Acta Criminologica 18(3):51-60.

Wilcox, P.W. and Land, K.C. (1996). "Perceived Risks Versus Fear of Crime: Empirical Evidence of Conceptually Distinct Reactions in Survey Data" Social Forces 74(4):1353-1376. 